\title{
PERAN SUAMI DALAM MENENTUKAN KESEJAHTERAAN SUBJEKTIF ISTRI PADA SAAT HAMIL DAN MELAHIRKAN
}

\author{
Sudirman $^{1^{*}}$, Herien Puspitawati ${ }^{2}$, Istiqlaliyah Muflikhati ${ }^{2}$ \\ ${ }^{1}$ Politeknik Baubau, Jl. Lakarambau Kota Baubau Sulawesi Tenggara, 93712, Indonesia \\ ${ }^{2}$ Departemen Ilmu Keluarga dan Konsumen, Fakultas Ekologi Manusia, Institut Pertanian Bogor, \\ Bogor 16680, Indonesia
}

*)E-mail: sudirmanykn@gmail.com

\begin{abstract}
Abstrak
Optimalisasi fungsi keluarga dapat diwujudkan dengan melakukan pembagian tugas pada setiap anggota keluarga sebagai bentuk upaya untuk meningkatkan status kesehatan dan gizi ibu hamil sehingga dapat menurunkan angka kematian ibu dan bayi di Indonesia. Penelitian ini bertujuan untuk menganalisis pengaruh peran suami terhadap kesejahteraan subjektif istri melahirkan. Desain penelitian menggunakan cross sctional study dan dilaksanakan di wilayah kerja Puskesmas Tuppu, Kecamatan Lembang, Kabupaten Pinrang, Provinsi Sulawesi Selatan dengan melibatkan 110 istri pada keluarga utuh dan memiliki anak berusia maksimal 6 bulan yang dipilih menggunakan metode simple random sampling. Data dikumpulkan melalui wawancara dengan menggunakan kuesioner dan selanjutnya dianalisis secara deskriptif dan uji regresi berganda. Hasil penelitian menemukan rata-rata peran suami pada saat istri hamil dan melahirkan berada pada kategori rendah, terutama pada dimensi peran domestik dan peran sosial. Kesejahteraan subjektif istri pada saat hamil dan melahirkan berada pada kategori sedang. Tipologi keluarga berdasarkan peran suami dan kesejahteraan subjektif istri sebagian besar tergolong kedalam tipe 2. Sementara itu, lama pendidikan suami, pendapatan keluarga dan peran suami pada dimensi peran domestik dan dimensi peran sosial berpengaruh positif signifikan terhadap kesejahteraan subjektif istri melahirkan.
\end{abstract}

Kata kunci: istri melahirkan, kesejahteraan subjektif, peran suami, tipologi keluarga

\section{Husband's Rule in Determining Subjective Well-Being Wife with Newly Born Baby}

\begin{abstract}
Optimization of family functions can be realized by dividing tasks for each family member as an effort to improve the health and nutrition status of pregnant women so that they can reduce maternal and infant mortality in Indonesia. The objective of this study is to analyze the influence of the role of husband on the subjective wellbeing of wife with newborn baby. The study design used a cross sectional study and carried out in Tuppu Health Center, Lembang Subdistrict, Pinrang Regency, South Sulawesi Province by involving 110 wives in intact families and was having children up to 6 months of age; selected using simple random sampling method. Data were collected through interviews using questionnaires then were analyzed by descriptive and multiple regression test. The results of the study found that the average role of husbands when his wife was pregnant and giving birth is in the low category, especially in the dimensions of domestic roles and social roles. Wife's subjective well-being is in the medium category. Family typology based on husband's role and wife's subjective well-being when was pregnant and giving birth are mostly classified into type 2. Meanwhile, the duration of husband's education, family income and husband's role in domestic role and social role dimensions have a significant positive effect on subjective well-being of wife with newborn baby.
\end{abstract}

Keywords: family typology, husbands' role, subjective well-being, wife with newly born baby

\section{PENDAHULUAN}

Kematian ibu dan bayi masih menjadi permasalahan yang harus diperhatikan dan ditangani dengan maksimal. Berdasarkan data dari ASEAN Statistical Report on Millennium Development Goals memperlihatkan bahwa Angka Kematian Ibu (AKI) berada pada kisaran 305 per 100.000 kelahiran hidup, masih sangat jauh dari target $A S E A N$ Millenium Development Goals yaitu 98 per 100.000 kelahiran hidup dan Angka Kematian Bayi (AKB) sebesar 22 per 1.000 kelahiran bayi (ASEAN MDGs, 2017). Salah satunya, kondisi tersebut mengindikasikan kondisi kesehatan ibu hamil atau melahirkan yang masih kekurangan vitamin atau mempunyai status gizi yang rendah (Madanijah et al., 
2013). Adanya berbagai permasalahan tersebut membutuhkan upaya untuk meningkatkan status gizi dan kesehatan ibu hamil dan atau melahirkan. Upaya yang perlu dilakukan bukan hanya terkait dengan pemenuhan gizi ibu hamil dan melahirkan namun juga upaya-upaya lain yang sifatnya menguatkan kondisi psikososialnya.

Salah satu upaya yang dapat dilakukan adalah dengan mengoptimalkan fungsi keluarga. Menurut Sunarti (2015), fungsi keluarga yang berjalan dengan optimal akan memiliki kemampuan menyediakan sumber daya untuk meningkatkan kualitas hidup keluarga. Fungsi keluarga mencakup fungsi ekspesif yaitu berkaitan dengan pemenuhan kebutuhan emosi dan perkembangan termasuk moral, loyalitas, dan sosialisasi; dan fungsi instrumental yang berkaitan dengan perolehan sumber daya ekonomi dan manajemen yang berlangsung sepanjang kehidupan keluarga. Levy dalam Megawangi (2014) memaparkan fungsi keluarga hanya bisa berjalan dengan baik jika dilakukan pembagian tugas yang jelas pada masing-masing anggota keluarga (aktor) berdasarkan statusnya dalam keluarga. Pembagian tugas yang dimaksud adalah alokasi peran pada setiap anggota di dalam keluarga (Megawangi, 2014). Hasil penelitian Putri dan Lestari (2015) menunjukkan pasangan berbagi peran dalam tiga bidang yaitu pengambilan keputusan, pengelolaan keuangan keluarga, dan pengasuhan anak; dengan proses implementasi peran yang fleksibel; dan suami memiliki peran yang lebih besar dalam pengambilan keputusan sementara istri dalam manajemen keuangan dan pengasuhan anak.

Sementara itu, istri dengan pengetahuan agama berdampak terhadap perilaku mengatur urusan rumah tangga dan mengelola keuangan keluarga (Inggriani \& Nafik, 2015). Namun, pada kondisi istri sedang hamil dan atau melahirkan, istri akan mengalami keluhan mual, muntah, pusing, dan mudah lelah, serta tingkat kecemasan tinggi (Rustikayanti, Kartika, \& Herawati, 2016), yang dapat menyebabkan aktivitas peran istri akan terganggu. Pada situasi tersebut diperlukan dukungan dan peran pengganti dari suami. Suami sebagai salah satu anggota dalam keluarga (sebagai orang paling dekat dengan istri) harus menjalankan perannya (Megawangi, 2014), baik peran pada wilayah produktif, wilayah domestik maupun peran sosial. Dukungan dan peran suami secara konsisten berhubungan dengan perilaku ibu hamil yang lebih sehat, seperti perawatan kehamilan lebih dini, mengurangi merokok, dan mengurangi konsumsi alkohol (Alio et al., 2010).

Selain itu, peran suami dalam hal menyediakan akses pelayanan kesehatan dan selalu mendampingi istri ketikal hamil dalam melakukan pemeriksaan kesehatan sebagai bentuk deteksi dini dan pencegahan komplikasi kehamilan juga merupakan bentuk dukungan yang sangat dibutuhkan. Hasil penelitian Widoyo (2015) menyatakan pentingnya peran suami sebagai orang terdekat dari ibu hamil. Peran ini dapat dilakukan dengan memiliki kepekaan yang tinggi; merespon setiap keluhan keluhan kecil yang dirasakan istri seperti mual, pusing, dan lemas; dan juga menganjurkan dan mendampingi istri untuk melakukan pemeriksaan terhadap keluhan tersebut. Dukungan suami terhadap istri ketika hamil juga memiliki dampak subjektif yang dirasakan istri seperti tingkat kecemasan yang lebih rendah terutama pada kehamilan trimester tiga/ periode akhir kehamilan (Diani \& Susilawati, 2013), kekuatan mental dan kepercayaan diri yang lebih tinggi yang dirasakan istri dalam menghadapi persalinan dan setelah persalinan (Umami \& Puspitasari, 2007; Widoyo, 2015). Hasil-hasil penelitian tersebut memperlihatkan adanya dampak positif pada kondisi kehamilan istri karena adanya dukungan peran suami saat istrinya sedang hamil. Dampak positif terhadap penurunan kecemasan dan peningkatan kepercayaan diri selama istri hamil dan melahirkan akan memengaruhi juga kepuasan istri terhadap kondisinya, mengingat berbagai perubahan fisiologis dan psikologis yang dialaminya.

Kepuasan adalah gambaran hidup yang berkualitas. Orang yang sejahtera dan merasa puas terhadap kehidupannya maka dapat dikatakan sebagai orang yang memiliki kualitas hidup yang baik (Tripathi, 2012). Menurut Diener et al. (1999), kesejahteraan subjektif merupakan konsep luas yang mencakup respon perasaan dan sikap positif dan negatif, kepuasan seseorang terhadap aspek tertentu dalam kehidupan mereka, dan penilaian kepuasan hidup secara menyeluruh. Kesejahteraan subjektif merupakan kepuasan terhadap kehidupan secara keseluruhan berdasarkan standar pribadi (Chen, Murayama, \& Kamibeppu, 2010). Peran suami merupakan peristiwa eksternal (external events) yang digambarkan Diener et al. (1999) sebagai bottom up factors yang merupakan salah satu pendekatan yang dapat digunakan 
mengukur kesejahteraan subjektif istri (Durayappah, 2010).

Lewis, Lee, dan Simkhada (2015) telah mengkaji peran suami dan kesehatan istri ketika hamil serta persalinan aman yang berfokus pada peran dukungan kesehatan dan aspek kesehatan fisik ibu hamil. Pada penelitian ini, peran suami dikaji pada aspek yang lebih luas yaitu mencakup peran suami pada wilayah pekerjaan rumah tangga, kesehatan kehamilan, persiapan melahirkan dan dukungan biaya, serta keterlibatan dalam lingkungan sosial. Kondisi istri yang difokuskan pada penelitian ini adalah kesejahteraan subjektif istri atau kepuasan yang dirasakan istri tentang kesehatan fisik, ketersediaan keuangan, dukungan keluarga luas, keamanan dan kenyamanan dengan keluarga selama periode kehamilan hingga persalinan.

Hipotesanya, jika peran suami pada semua aspek dilakukan dengan baik dan penuh tanggung jawab maka istri ketika hamil dan melahirkan akan merasakan kesejahteraan subjektif (kepuasan dan keahagiaan) yang optimal. Mengingat pentingnya hal tersebut, maka perlu dilakukan kajian tentang peran suami dalam menentukan kesejahteraan subjektif istri ketika hamil dan melahirkan. Berdasarkan latar belakang yang telah diuraikan maka penelitian ini diarahkan untuk mencapai tujuan untuk: 1) mengidentifikasi karakteristik istri dan keluarga, peran suami dan kesejahteraan subjektif istri ketika hamil dan melahirkan; 2) menganalisis tipologi keluarga berdasarkan kesejahteraan subjektif istri ketika hamil dan melahirkan dan peran suami; 3) menganalisis pengaruh peran suami terhadap kesejahteraan subjektif istri ketika hamil dan melahirkan.

\section{METODE}

Penelitian ini menggunakan desain cross sectional study yang dilakukan di wilayah kerja Puskesmas Tuppu, Kecamatan Lembang, Kabupaten Pinrang, Provinsi Sulawesi Selatan. Penentuan lokasi penelitian dilakukan secara purposive berdasarkan jumlah kelahiran di Puskesmas Tuppu.

Teknik penarikan contoh menggunakan metode simple random sampling. Jumlah contoh sebanyak 110 orang dari total populasi sebanyak 156 orang. Populasi pada penelitian ini adalah keluarga lengkap yang memiliki anak maksimal berumur enam bulan yang tinggal di wilayah kerja Puskesmas Tuppu, Kecamatan Lembang, Kabupaten Pinrang.
Data primer dikumpulkan melalui wawancara dengan menggunakan kuesioner. Data karakteristik keluarga yang dikumpulkan mencakup pendidikan istri, pendidikan suami, usia istri, usia suami, besar keluarga, dan pendapatan keluarga. Pendidikan istri dan suami diukur menggunakan lama waktu menempuh pendidikan formal (tahun) yang kemudian dikategorikan menjadi 0-6 tahun setara dengan SD, 7-9 tahun setara dengan SMP, 10-12 tahun setara dengan SMA dan 1316 tahun setara dengan pendidikan tinggi. Usia istri dan suami yang juga diukur dengan tahun selanjutnya dikategorikan dengan kategori dewasa awal (20-40 tahun), dewasa madya (41-60 tahun), dan dewasa lanjut (>60 tahun). Jumlah anggota keluarga (orang) selanjutnya dikategorikan sebagai besar keluarga yang terdiri dari keluarga kecil ( $\leq 4$ orang), keluarga sedang (5-7 orang) dan keluarga besar ( $\geq 8$ orang). Pendapatan keluarga dilihat berdasarkan besarnya pendapatan yang diperoleh keluarga setiap bulan (Rp/bulan).

Variabel peran suami adalah aktivitas yang dilakukan oleh suami yang mencakup aspek domestik, produktif, dan sosial untuk mewujudkan kesejahteraan keluarga. Peran suami pada penelitian ini diukur dengan tiga dimensi yaitu dimensi peran domestik, peran produktif, dan peran soaial. Peran suami diukur dengan menggunakan kuesioner yang dimodifikasi peneliti dengan mengacu pada Moser yang dikembangkan Puspitawati (2012). Dalam kuesioner tersebut, terdapat 25 pernyataan yang diukur dalam tiga jawaban, yaitu jawaban $1=$ tidak pernah, jawaban $2=$ kadang-kadang dan jawaban $3=$ sering dengan nilai Cronbach's alpha sebesar 0,793. Sementara itu, variabel kesejahteraan subjektif istri ketika melahirkan diukur dari kebahagiaan/kepuasan pada aspek fisik, ekonomi, psikologis dan sosial yang dirasakan istri dengan kehidupannya selama periode kehamilan hingga persalinan. Kesejahteraan subjektif istri diukur menggunakan kuesioner yang dimodifikasi peneliti dengan mengacu pada Quality of Life University of Toronto (2008) yang sebelumnya telah dikembangkan Puspitawati (2009). Kuesioner menggunakan 23 pernyataan dan masing-masing pernyataan disediakan empat jawaban, yaitu jawaban 1= sangat tidak puas, jawaban $2=$ tidak puas, jawaban $3=$ puas dan jawaban $4=$ sangat puas dengan nilai Cronbach's alpha sebesar 0,875 .

Data yang telah dikumpulkan selanjutnya diolah dan dianalisis menggunakan program Microsoft Excel dan Statistical Package for 
Social Science (SPSS) for Windows. Proses pengolahan data dilakukan melalui editing, coding, entrying dan cleaning. Berdasarkan data yang dikumpulkan diperoleh skor setiap respondon dengan jumlah skor minimal 25 dan skor maksimal 75 pada variabel peran suami serta skor minimal 23 dan skor maksimal 92 untuk variabel kesejahteraan subjektif istri. Skor yang diperoleh selanjutnya itransformasikan menjadi indeks untuk menyeragamkan nilai maksimum dan minimum serta penyeragaman kategori.

Nilai indeks yang diperoleh selanjutnya dikategorikan berdasarkan pada Bloom's cut off (Wanyama et al., 2015) yaitu 00,0-60,0 dikategorikan rendah, 60,0-80,0 dikategorikan sedang, dan 80,0-100 dikategorikan tinggi. Selanjutnya, dilakukan analisis deskriptif untuk menggambarkan karakteristik keluarga, peran suami, dan kesejahteraan subjektif istri yang dinyatakan dalam nilai rata-rata, minimum, maksimum dan distribusi responden. Analisis tipologi untuk menggambarkan sebaran tipologi keluarga berdasarkan peran suami dan kesejahteraan subjektif istri menjadi empat tipe, yaitu Tipe 1 yang dicirikan oleh peran suami rendah sedangkan kesejahteraan subjektif istri tinggi; Tipe 2 yang dicirikan oleh peran suami tinggi dan kesejahteraan subjektif istri tinggi; Tipe 3 yang dicirikan oleh peran suami tinggi tetapi kesejahteraan subjektif istri rendah, dan Tipe 4 yang dicirikan oleh peran suami rendah dan kesejahteraan subjektif istri rendah. Peran suami dan kesejahteraan subjektif istri dinyatakan rendah jika nilai ratarata indeks kurang dari $60(<60)$ dan tinggi apabila lebih besar atau sama dengan 60 $(\geq 60)$. Uji regresi berganda digunakan untuk menguji pengaruh karakteristik keluarga dan peran suami terhadap kesejahteraan subjektif istri. Suatu variabel dinyatakan memiliki hubungan dan atau pengaruh terhadap variabel lain apabila memiliki nilai signifikansi $p$ $<0,05$.

\section{HASIL}

\section{Karakteristik Istri dan Keluarga}

Hasil penelitian memperlihatkan bahwa persentase tertinggi istri $(38,2 \%)$ dan suami $(41,8 \%)$ adalah mempunyai tingkat pendidikan Sekolah Dasar dengan rata-rata pendidikan suami 9,36 tahun dan istri 9,87 tahun. Hasil penelitian menunjukkan bahwa sebagian besar istri $(93,6 \%)$ dan suami $(83,6 \%)$ berada pada periode dewasa awal dengan rata-rata usia istri 30,65 tahun dan usia suami 34,24 tahun. Rata-rata keluarga pada penelitian ini memiliki anggota keluarga sebanyak 4 orang, dan hampir tiga perempat keluarga (72,7\%) tergolong pada kategori keluarga kecil. Proporsi tertinggi keluarga $(44,5 \%)$ memiliki pendapatan berada pada kisaran Rp2.250.000,00 hingga Rp4.500.000,00 per bulan dengan rata-rata pendapatan keluarga sebesar Rp3.056.363,64 per bulan. Rata-rata pendapatan keluarga tersebut berada di atas garis nilai Upah Minimum Provinsi (UMP) Sulawesi Selatan yaitu sebesar Rp2.250.000.

\section{Peran Suami}

Hasil penelitian ini menemukan bahwa secara keseluruhan, proporsi tertinggi suami $(53,6 \%)$ berada pada kategori peran yang rendah dan hanya 12,7 persen peran suami yang berada pada kategori tinggi. Nilai rata-rata indeks peran suami ditemukan sebesar 57,88 .

Dimensi Peran Domestik. Penelitian menunjukkan bahwa lebih dari dua per tiga suami $(68,2 \%)$ berada pada kategori peran domestik rendah dengan rata-rata indeks 47,05 . Sebagian besar suami hanya sekalisekali dan bahkan sebagian besar lainnya tidak pernah melakukan aktivitas domestik terutama yang berhubungan dengan pekerjaan rumah tangga. Suami tidak pernah dan atau hanya sekali-sekali membantu istri mencuci pakaian dan alat rumah tangga; membersihkan rumah seperti menyapu rumah dan halaman; memasak dan menyediakan makanan; dan berbelanja kebutuhan keluarga sehari-hari saat istri sedang hamil dan atau melahirkan. Rendahnya peran suami atau keterlibatan suami dalam pekerjaan rumah tangga diduga disebabkan oleh kesibukan suami pada pekerjaan di luar rumah sebagai pencari nafkah.

Tabel 1 Sebaran istri berdasarkan kategori dimensi peran suami serta nilai ratarata, minimum, dan maksimum indeks peran suami

\begin{tabular}{|c|c|c|c|c|}
\hline \multirow{2}{*}{ Kategori } & \multicolumn{3}{|c|}{ Dimensi Peran Suami (\%) } & \multirow{2}{*}{$\begin{array}{l}\text { Total } \\
\text { Peran } \\
\text { Suami }\end{array}$} \\
\hline & Domestik & Produktif & Sosial & \\
\hline $\begin{array}{l}\text { Rendah } \\
(00,0-60,0)\end{array}$ & 68,2 & 9,1 & 65,5 & 53,6 \\
\hline $\begin{array}{l}\text { Sedang } \\
(60,0-80,0)\end{array}$ & 27,3 & 41,8 & 29,1 & 33,6 \\
\hline $\begin{array}{l}\text { Tinggi } \\
(80,0-100,0)\end{array}$ & 4,5 & 49,1 & 5,5 & 12,7 \\
\hline Total & 100,0 & 100,0 & 100,0 & 100,0 \\
\hline $\begin{array}{l}\text { Min-Maks } \\
(0-100)\end{array}$ & $15-94$ & $38-100$ & $\begin{array}{l}13- \\
100\end{array}$ & $\begin{array}{c}27- \\
90\end{array}$ \\
\hline $\begin{array}{l}\text { Rata- } \\
\text { rata } \pm S t d\end{array}$ & $\begin{array}{c}47,05 \pm \\
20,86 \\
\end{array}$ & $\begin{array}{c}79,35 \pm \\
13,99 \\
\end{array}$ & $\begin{array}{c}47,15 \pm \\
22,85 \\
\end{array}$ & $\begin{array}{r}57,88 \pm \\
17,17 \\
\end{array}$ \\
\hline
\end{tabular}


Disamping itu, keterlibatan keluarga besar (seperti orang tua, mertua, kakak, adik, dan saudara ipar) dalam aktivitas yang berhubungan dengan pekerjaan rumah tangga pada keluarga partisipan penelitian sangat tinggi. Keluarga besar merasa memiliki tanggung jawab terhadap tugas-tugas yang tidak dapat dilakukan oleh istri dalam kondisinya yang sedang hamil dan atau melahirkan.

Dimensi Peran Produktif. Tabel 1 memperlihatkan nilai rata-rata indeks dimensi peran produktif suami sebesar 79,35 , dengan proporsi terbesar $(49,1 \%)$ berada pada kategori tinggi dan hanya sebesar 9,1 persen suami mempunyai peran produktif pada kategori rendah. Analisis butir pertanyaan menemukan bahwa suami telah menyediakan keuangan yang cukup untuk kebutuhan keluarga dan persiapan persalinan istri. Selain itu, suami juga telah menyediakan keuangan untuk memenuhi kebutuhan gizi selama kehamilan hingga persalinan istri dan suami mencari penghasilan tambahan untuk persiapan keuangan selama kehamilan hingga persalinan istri

Dimensi Peran Sosial. Hasil penelitian menunjukkan bahwa proporsi tertinggi suami $(65,5 \%)$ mempunyai dimensi peran sosial pada kategori rendah dengan nilai rata-rata indeks sebesar 47,15 . Selain itu, hasil penelitian juga menemukan bahwa lebih dari setengah suami hanya sekali-sekali meluangkan waktu bersama istri bersosialisasi dengan tetangga dan satu dari tiga suami tidak pernah mendukung istri agar berpartisipasi pada kegiatan berbasis perempuan (seperti kegiatan PKK) di lingkungan tempat tinggal. Hasil lain menemukan bahwa lebih dari dua per tiga suami tidak kerap mendukung istri berpartisipasi pada kegiatan selamatan/ syukuran (misalnya pesta pernikahan, acara adat) di lingkngan tempat tinggal.

\section{Kesejahteraan Subjektif Istri}

Secara keseluruhan, hasil penelitian memperlihatkan bahwa secara umum proporsi tertinggi istri $(43,6 \%)$ berada pada kategori kesejahteraan subjektif kategori sedang pada saat melahirkan dengan rata-rata indeks sebesar 62,84 .

Dimensi Kesejahteraan Fisik. Tabel 2 memperlihatkan bahwa lebih dari separuh istri $(53,6 \%)$ mempunyai kesejahteraan subjektif dimensi fisik pada kategori sedang dengan nilai rata-rata indeks 65,28.
Tabel 2 Sebaran istri berdasarkan kategori dimensi kesejahteraan subjektif serta nilai rata-rata, minimum, dan maksimum indeks kesejahteraan subjektif istri pad asaat melahirkan Dimensi Kesejahteraan Subjekif Total

\begin{tabular}{|c|c|c|c|c|c|}
\hline \multirow{2}{*}{ Kategori } & \multicolumn{4}{|c|}{$\begin{array}{c}\text { Dimensi Kesejahteraan Subjekif } \\
(\%)\end{array}$} & \multirow[t]{2}{*}{ Total } \\
\hline & Fisik & Ekonomi & Sosial & Psikologis & \\
\hline $\begin{array}{l}\text { Rendah } \\
(00,0-\end{array}$ & 30,9 & 87,3 & 26,4 & 34,5 & 42,7 \\
\hline $\begin{array}{l}\text { Sedang } \\
(60,0- \\
80,0)\end{array}$ & 53,6 & 12,7 & 44,5 & 41,8 & 43,6 \\
\hline $\begin{array}{l}\text { Tinggi } \\
(80,0- \\
100,0)\end{array}$ & 15,5 & 0 & 29,1 & 23,6 & 13,6 \\
\hline Total & 100 & 100 & 100 & 100 & 100 \\
\hline $\begin{array}{l}\text { Min- } \\
\text { Maks } \\
(0-100)\end{array}$ & $\begin{array}{l}40- \\
100\end{array}$ & $17-75$ & $\begin{array}{l}43- \\
100\end{array}$ & $42-100$ & $\begin{array}{c}44- \\
88\end{array}$ \\
\hline $\begin{array}{l}\text { Rata- } \\
\text { rata } \pm S t d\end{array}$ & $\begin{array}{c}65,28 \\
\pm \\
15,01\end{array}$ & $\begin{array}{l}46,77 \pm \\
11,30\end{array}$ & $\begin{array}{c}71,14 \\
\pm \\
13,57\end{array}$ & $\begin{array}{l}67,76 \pm \\
14,30\end{array}$ & $\begin{array}{c}62,84 \\
\pm \\
11,59\end{array}$ \\
\hline
\end{tabular}

Hasil analisis butir pertanyaan menemukan istri merasa puas dengan kondisi kesehatannya selama kehamilan sampai melahirkan. Akan tetapi, hampir sepertiga istri merasa tidak puas terhadap ketersediaan biaya pengobatan jika kesehatan istri pada saat hamil terganggu (sakit). Selain itu, lebih dari setengah istri merasa puas dengan kemudahan mengakses pelayanan kesehatan (kehamilan-persalinan), pemenuhan kebutuhan sehari-hari, ketersediaan makanan dan minuman untuk memenuhi gizi ibu selama kehamilan.

Dimensi Kesejahteraan Ekonomi. Penelitian memperlihatkan bahwa sebesar 87,3 persen istri mempunyai kesejahteraan subjektif dimensi ekonomi istri pada kategori rendah, dengan kata lain lebih dari tiga perempat istri merasa tidak puas dengan kondisi ekonomi yang dimiliki saat hamil dan melahirkan. Hasil penelitian juga menemukan bahwa terdapat lima dari sepuluh istri merasa tidak puas dengan kepemilikan barang berharga (misalnya perhiasan, kendaraan, perumahan, kebun, sawah dan lain-lain). Sementara itu, hampir setengah istri merasa tidak puas terhadap pendapatan keluarga, kondisi tabungan, dan investasi keluarga dalam bentuk uang. Selain itu, istri juga merasa kurang puas dengan kemampuan keluarga dalam membiayai pemeriksaan kehamilan, persiapan biaya persalinan, dan biaya persiapan untuk keperluan calon bayi.

Dimensi Kesejahteraan Sosial. Hasil penelitian menemukan bahwa rata-rata indeks 
kesejahteraan subjektif istri pada dimensi sosial sebesar 71,14 dengan proporsi tertinggi $(44,5 \%)$ berada pada kategori sedang. Hasil ini menunjukkan bahwa hampir setengah istri pada penelitian ini merasa cukup puas terhadap hubungan sosial yang dijalani saat ini. Sementara itu, lebih dari setengah istri merasa puas terhadap komunikasi atau hubungan baik dengan suami dan hubungan baik dengan keluarga luas (seperti orang tua, mertua, kakak-adik, ipar, paman, bibi), serta merasa puas terhadap dukungan keluarga luas selama kehamilan hinggga melahirkan. Hasil lain juga menunjukkan bahwa lebih dari setengah istri merasa cukup puas terhadap hubungan dengan tetangga dan keterlibatan dalam kegiatan sosial dan keagamaan di lingkungan tempat tinggal.

Dimensi Kesejahteraan Psikologis. Seperti yang tersaji pada Tabel 2, hasil penelitian menunjukkan bahwa kesejahteraan subjektif istri melahirkan pada dimensi psikologis, proporsi terbesarnya $(41,8 \%)$ berada pada kategori sedang. Hasil penelitian menunjukkan bahwa hampir dua per tiga istri melahirkan merasa aman dan nyaman dengan kondisi keluarganya. Selain itu, sebagian besar istri merasa puas terhadap respon suami/keluarga pada saat ibu "ngidam" (ingin makan sesuatu dan harus ada pada saat itu juga, mual, muntah) pada masa kehamilannya. Hasil lain juga menunjukkan bahwa lebih dari dua per tiga istri merasa puas mengenai pengelolaan waktu mengurus rumah dan mengurus bayi setelah melahirkan

\section{Tipologi Keluarga berdasarkan Kesejahteraan Subjektif Istri dan Peran Suami}

Analisis tipologi keluarga berdasarkan kesejahteraan subjektif istri pada saat hamil dan melahirkan serta peran suami pada Gambar 1 dapat dijelaskan bahwa garis vertikal merupakan kesejahteraan subjektif istri pada saat hamil dan melahirkan dengan ketentuan semakin keatas menandakan kesejahteraan subjetif istri semakin tinggi. Sementara itu, garis horizontal merupakan peran suami, dengan ketentuan semakin ke kanan menandakan peran suami yang semakin tinggi. Hasil menunjukkan bahwa tipologi keluarga pada penelitian ini, proporsi terbesarnya $(45,5 \%)$ adalah keluarga Tipe 2, yaitu dengan kesejahteraan subjektif istri pada saat hamil dan melahirkan tinggi serta peran suami tinggi. Selanjutnya, proporsi terbesar kedua $(40,9 \%)$ adalah keluarga Tipe 4 , yaitu keduanya rendah baik kesejahteraan subjektif istri pada saat hamil dan melahirkan serta peran suami.

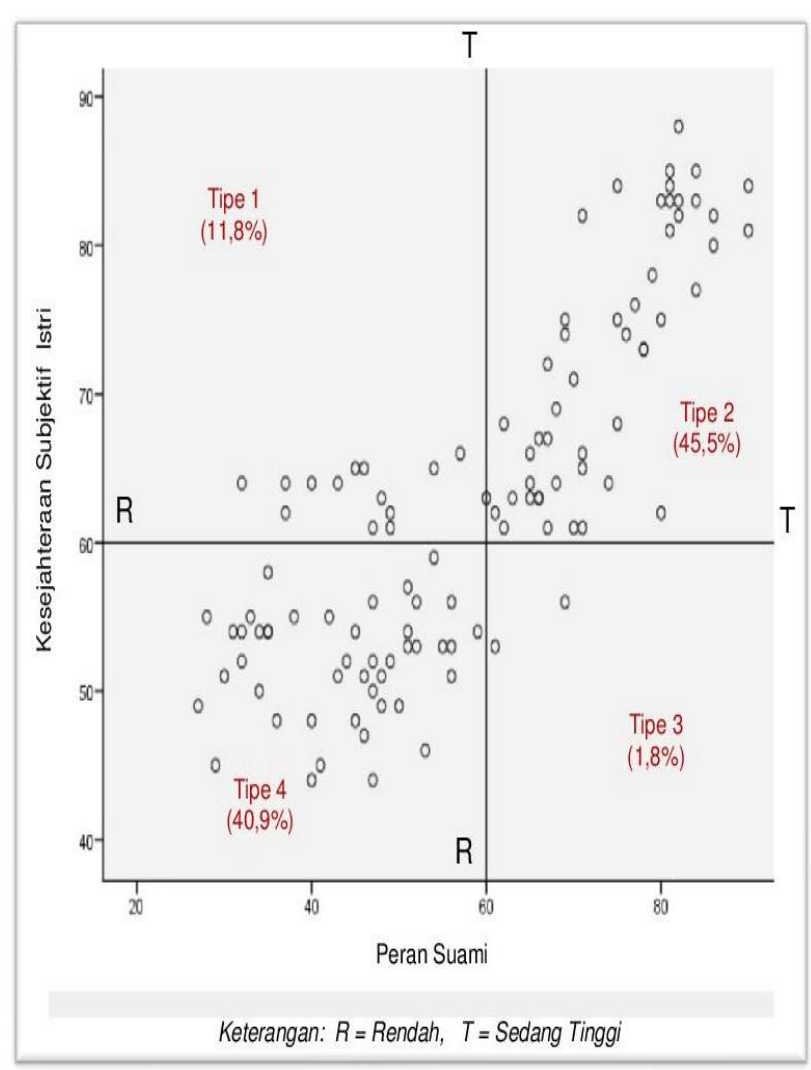

Gambar 1 Sebaran tipologi keluarga berdasarkan kesejahteraan

subjektif istri pada saat hamil dan melahirkan serta peran suami

\section{Pengaruh Karakteristik Keluarga dan Peran Suami terhadap Kesejahteraan Subjektif Istri pada Saat Hamil dan Melahirkan}

Hasil analisis regresi berganda (Tabel 3) menunjukkan nilai koefisien determinasi (Adjusted $R$ Square) sebesar 0,747. Nilai ini menyatakan besarnya pengaruh variabel usia suami, perbedaan usia suami dan istri, lama pendidikan suami, pendapatan keluarga, besar keluarga, dimensi peran domestik suami, dimensi peran produktif suami, dan dimensi peran sosial suami terhadap variabel kesejahteraan subjektif istri ketika hamil dan melahirkan. Nilai koefisien ini menjelaskan bahwa sebesar 74,7 persen keberagaman kesejahteraan subjektif istri ketika hamil dan melahirkan dapat dijelaskan oleh variabel bebas pada penelitian ini, sedangkan sisanya dijelaskan oleh variabel lain yang tidak terdapat dalam model. Nilai koefisien regresi variabel pendidikan suami ditunjukkan dengan $\mathrm{B}=0,714, \mathrm{p}<0,05$ yang menunjukkan bahwa nilai indeks kesejahteraan subjektif istri ketika hamil dan melahirkan. 
Tabel 3 Pengaruh karakteristik keluarga dan dimensi peran suami terhadap kesejahteraan subjektif Istri

\begin{tabular}{|c|c|c|c|}
\hline \multirow[t]{2}{*}{ Variabel } & \multicolumn{2}{|c|}{$\begin{array}{c}\text { Kesejahteraan } \\
\text { Subjektif }\end{array}$} & \multirow[t]{2}{*}{ Sig } \\
\hline & (B) & $(\beta)$ & \\
\hline Usia suami & $-0,044$ &,- 022 & 0,743 \\
\hline $\begin{array}{l}\text { Perbedaan usia } \\
\text { suami dan istri }\end{array}$ & $-0,163$ &,- 052 & 0,359 \\
\hline $\begin{array}{l}\text { Lama Pendidikan } \\
\text { Suami (tahun) }\end{array}$ & 0,714 & ,205 & $0,019^{*}$ \\
\hline $\begin{array}{l}\text { Pendapatan } \\
\text { Keluarga (ratusan } \\
\text { ribu rupiah) }\end{array}$ & 0,134 & 203 & $0,009^{* \pi}$ \\
\hline $\begin{array}{l}\text { Besar keluarga } \\
\text { (orang) }\end{array}$ & $-0,806$ &,- 076 & 0,227 \\
\hline $\begin{array}{l}\text { Dimensi Peran } \\
\text { Domestik (indeks) }\end{array}$ & 0,200 & ,360 & $0,000^{* \pi}$ \\
\hline $\begin{array}{l}\text { Dimensi Peran } \\
\text { Produktif (indeks) }\end{array}$ & $-0,012$ &,- 015 & 0,830 \\
\hline $\begin{array}{l}\text { Dimensi Peran } \\
\text { Sosial (indeks) }\end{array}$ & 0,115 & ,227 & $0,007^{\pi \times}$ \\
\hline $\mathrm{F}$ & 41,321 & & \\
\hline Adjusted R Square & 0,747 & & \\
\hline Sig & $0,000^{\pi \pi}$ & & \\
\hline
\end{tabular}

Hal tersebut berarti berarti kesejahteraan subjektif istri dapat meningkat sebesar 0,714 apabila lama pendidikan suami bertambah satu tahun. Temuan tersebut menjelaskan bahwa semakin tinggi jenjang pendidikan yang ditempuh oleh suami akan semakin tinggi pula kesejahteraan subjektif yang dirasakan istri, khususnya ketika hamil dan melahirkan. Pendidikan suami menunjukkan adanya pengaruh positif signifikan terhadap kesejahteraan subjektif istri.

Selain itu, pendapatan keluarga pada penelitian ini juga menunjukkan pengaruh positif terhadap kesejahteraan subjektif istri ketika hamil dan melahirkan. Besarnya pengaruh pendapatan keluarga terhadap kesejahteraan subjektif istri ketika hamil dan melahirkan ditunjukkan oleh besarnya nilai koefisien regresi sebesar $B=0,134$. Besarnya nilai koefisien tersebut mengandung makna bahwa nilai indeks kesejahteraan subjektif istri meningkat sebesar 0,134 ketika pendapatan keluarga meningkat seratus ribu rupiah. Temuan ini menjelaskan bahwa istri pada keluarga yang memiliki pendapatan keluarga lebih besar cenderung memiliki kesejahteraan subjektif yang lebih tinggi dibandingkan keluarga yang memiliki pendapatan lebih rendah, khususnya pada saat istri hamil dan melahirkan.

Hasil analisis regresi berganda pada Tabel 3 juga memperlihatkan bahwa peran suami pada dimensi peran domestik $(B=0,200, p<0,01)$ dan dimensi peran sosial $(B=0,115, p<0,01)$ berpengaruh positif secara nyata terhadap kesejahteraan subjektif istri ketika hamil dan melahirkan. Variabel dimensi peran domestik dapat meningkatkan nilai indeks kesejahteraan subjektif istri sebesar 0,200 ketika satu satuan nilai indeks variabel tersebut meningkat. Sementara itu, variabel dimensi peran sosial juga mampu meningkatkan kesejahteraan subjektif istri, yaitu setiap kenaikan satu satuan nilai indeks variabel dimensi peran sosial suami maka akan menaikkan nilai indeks kesejahteraan subjektif istri sebesar 0,115 . Hal ini dapat diartikan bahwa suami yang sering membantu istrinya melakukan aktifitas domestik (seperti memasak, mencuci pakaian, dan membersihkan rumah saat istri hamil dan atau melahirkan, mendampingi istri melakukan pemeriksaan kehamilan, menyediakan sejumlah uang (tabungan) untuk persiapan persalinan, dan mendampingi istri saat melahirkan) dan melakukan aktifitas sosial (seperti suami mendukung istri berpartisipasi dalam kegiatan pengajian/keagamaan), dan kegiatan berbasis perempuan (seperti kegiatan PKK) maka dapat meningkatkan kesejahteraan subjektif istri yang sedang hamil dan atau melahirkan.

\section{PEMBAHASAN}

Penelitian ini memperlihatkan persepsi istri dalam memberikan gambaran tentang kepuasan yang dirasakan secara subjektif selama kehamilan hingga melahirkan dikaitkan dengan peran suami. Istri merupakan salah satu anggota keluarga yang memiliki fungsi dan peran untuk mewujudkan kesejahteraan keluarga. Disamping sebagai pengatur rumah tangga dan anak, dalam kondisi tertentu istri juga dapat berperan sebagai pencari nafkah (Kartika \& Kanada, 2017). Pendekatan struktural fungsional dalam penelitian ini melibatkan peran dan fungsi suami dalam berbagai dimensi. Pertama, yaitu dimensi peran domestik yang merujuk pada peran suami yang berkaitan dengan pekerjaan rumah tangga (Utamidewi, 2017); kesehatan istri selama kehamilan seperti mendampingi dan mangantar istri ke pusat pelayanan kesehatan dan persiapan persalinan seperti menyediakan biaya (Carter, 2002); mendampingi istri saat melahirkan (Sapkota et al.); menyediakan transportasi, dukungan emosional (Furuta \& Salwaway, 2006). Peran kedua adalah pada dimensi peran produktif seperti menyediakan sumber daya rumah tangga (Furuta \& Salwaway, 2006). Ketiga, peran sosial/kemasyarakatan sebagai bagian dari upaya mewujudkan kesejahteraan subjektif istri selama kehamilan hingga melahirkan. 
Hasil penelitian menunjukkan bahwa pendidikan suami berpengaruh positif signifikan terhadap kesejahteraan subjektif istri ketika hamil dan melahirkan. Penelitian ini menemukan bahwa semakin tinggi pendidikan suami maka semakin tinggi pula peluang bagi istri merasakan kepuasan pada berbagai aspek kehidupannya saat hamil dan atau melahirkan. Hal ini disebabkan suami yang memiliki pendidikan tinggi memperoleh informasi dan pengetahuan mengenai dukungan dan cara memperhatikan istri ketika hamil dan atau melahirkan, sehingga istri merasa puas dan bahagia. Hasil penelitian ini sejalan dengan penelitian Kusumo, Sunarti dan Pranadji (2008); Puspitawati, Simanjuntak, dan Hayati (2012) yang juga menemukan bahwa lama pendidikan suami berpengaruh positif signifikan terhadap kesejahteraan subjektif keluarga. Keluarga dengan suami yang jenjang pendidikannya lebih tinggi akan berdampak pada kesejahteraan keluarga yang lebih tinggi. Sejalan dengan penelitian ini, Aceleanu (2012) menyatakan bahwa sangat sedikit kemungkinan terdapat kualitas hidup yang tinggi di dalam kelompok masyarakat dengan status pendidikan yang rendah. Hasil ini sesuai dengan kajian Zhang \& Liu (2007) yang menyatakan bahwa kesejahteraan subjektif dipengaruhi oleh pendidikan, umur, gender dan status finansial.

Pendapatan keluarga merupakan akumulasi penghasilan istri dan suami serta anggota keluarga lainnya yang digunakan untuk memenuhi kebutuhan bersama maupun perseorangan anggota keluarga dan merupakan unsur penting dalam mewujudkan tujuan keuangan keluarga (Joo \& Grable, 2004). Pendapatan keluarga merupakan salah satu sumber daya ekonomi keluarga dan merupakan faktor yang dapat berkontribusi terhadap kesejahteraan subjektif keluarga (Kim \& Moen, 2002). Hasil penelitian menemukan bahwa pendapatan keluarga berpengaruh positif signifikan terhadap kesejahteraan subjektif istri ketika hamil dan melahirkan. Penelitian ini menemukan bahwa semakin tinggi pendapatan keluarga maka semakin tinggi pula peluang istri merasakan kepuasan dan kebahagiaan di dalam kehidupannya, khususnya ketika hamil dan melahirkan. Hal ini berarti keluarga yang memiliki pendapatan maksimal dapat memenuhi semua kebutuhannya sehingga istri merasa puas. Pendapatan keluarga yang tinggi akan meningkatkan peluang bagi istri dan anggota keluarga lainnya menjadi sejahtera (Hartoyo \& Aniri, 2010). Hasil penelitian ini juga didukung peneltian Raharjo, Puspitawati, dan Krisnatuti
(2015); Muladsih, Muflikhati dan Herawati (2011) yang menemukan bahwa pendapatan per kapita berpengaruh terhadap kesejahteraan subjektif. Berkaitan dengan hal tersebut, Diener dan Seligman (2004) mengemukakan bahwa peningkatan pendapatan dan hubungan sosial memainkan peran penting pada peningkatan kesejahteraan subjektif. Kepuasan hidup yang dirasakan keluarga semakin besar seiring dengan semakin baiknya kondisi keuangan keluarga (Gray, Ventis, \& Hayslip, 1992). Pendapatan keluarga yang dikelola berdasarkan prinsip tata kelola keuangan keluarga yang baik akan menghasilkan tingkat kepuasan keuangan yang baik (Joo \& Greble, 2004; Plagnol, 2011).

Peran suami pada penelitian ini merupakan implementasi dari makna pembagian tugas yang jelas pada setiap anggota keluarga agar fungsi keluarga sebagai suatu sistem dapat berjalan dengan baik dan selanjutnya akan memengaruhi sistem yang lebih besar (Levy dalam Megawangi 2014). Peran suami secara umum pada penelitian ini berada pada kategori rendah. Rendahnya peran suami khususnya pada aspek peran domestik yang ditemukan pada penelitian ini dipengaruhi oleh cara pandang sebagian besar suami bahwa aktivitas domestik seperti pekerjaan rumah tangga dan perawatan anak dianggap sebagai kegiatan yang harus dilakukan oleh wanita (Lewis, Lee, \& Simkhada, 2015). Selain itu, penyebab lain adalah kesibukan suami pada pekerjaan di luar rumah sebagai pencari nafkah keluarga. Hal ini didukung oleh temuan Liamputtong dan Naksook (2003) yang menjelaskan bahwa beberapa wanita Thailand di Australia menyatakan bahwa suami mereka tidak memberikan dukungan yang memadai dalam urusan perawatan anak. Selain itu, sebagian besar suami bekerja dan tidak ingin melakukan pekerjaan ekstra yang berkitan dengan urusan rumah tangga dan anak.

Selanjutnya, hasil analisis tipologi keluarga berdasarkan kesejahteraan subjektif istri ketika hamil dan melahirkan dan peran suami pada penelitian ini menempatkan dua kelompok tipe yang memiliki proporsi tertinggi, yaitu Tipe 2 dan Tipe 4. Meskipun kedua tipe ini memiliki nilai persentase yang berbeda, namun nilai persentase tersebut selisihnya tergolong rendah. Keluarga yang berada pada Tipe 2 merupakan keluarga dengan peran suami tinggi dan kesejahteraan subjektif istri ketika hamil dan melahirkan juga tinggi. Hal ini menggambarkan bahwa ketika istri sedang hamil dan atau melahirkan mendapatkan dukungan peran suami secara optimal dan 
merasakan kepuasan dan kebahagiaan terhadap berbagai aspek kehidupannya. Sementara pada kelompok Tipe 4 merupakan tipologi keluarga dengan peran suami rendah dan kesejahteraan subjektif istri ketika hamil dan melahirkan juga rendah. Artinya, istri yang berada pada tipe ini mendapatkan dukungan peran suami yang rendah dan merasakan kesejahteraan subjektif juga rendah. Kesejahteraan subjektif istri yang dikaitkan dengan peran suami pada penelitian ini didasarkan pada bottom up factors yaitu salah satu pendekatan teori yang dapat digunakan untuk mengukur kesejahteraan subjektif (Durayappah, 2010). Teori ini menyatakan bahwa kebahagiaan dan kepuasan hidup yang dirasakan seseorang tergantung dari banyaknya kejadian-kejadian positif/bahagia yang dialami. Oleh karenanya, untuk meningkatkan kesejahteraan subjektif, seseorang perlu mengubah lingkungan (termasuk pola interaksi, peran dan fungsi setiap individu di dalam lingkungan keluarga) dan situasi yang akan memengaruhi pengalamannya. Sementara Diener, et al. (1999) menggambarkan bottom up factors sebagai peristiwa eksternal (external events), situasi (situations), dan demografi (demographics). Peran suami pada penelitian ini merupakan external events yang menurut pendekatan teori ini dapat dihubungkan dengan kesejahteraan subjektif. Hasil ini sejalan dengan penelitian Lewis, Lee, dan Simkhada (2015) yang dinyatakan pada simpulan penelitiannya bahwa keterlibatan atau peran suami yang lebih besar berpotensi memberikan manfaat yang lebih besar pula bagi kesehatan ibu hamil dan anak

Hasil analisis regresi memperlihatkan adanya pengaruh posistif signifikan peran suami terutama peran domestik dan peran sosial suami terhadap kesejahteraan subjektif istri. Hasil ini dapat menjelaskan bahwa istri akan merasakan kepuasan lebih tinggi di dalam kehidupannya seiring dengan meningkatnya dukungan peran suami dalam keluarga. Hasil penelitian ini menemukan bahwa suami yang menjalankan peran domestik (membantu istri dalam pekerjaan rumah tangga) dan peran sosial (bersosialisasi dengan lingkungan sekitar) secara optimal akan meningkatkan kepuasan istri, khususnya ketika hamil dan melahirkan. Hal ini sejalan dengan beberapa temuan penelitan sebelumnya seperti penelitian Mageni et al. (2013) yang mengemukakan bahwa suami yang berperan dengan baik dalam menjaga dan merawat istri; serta penelitian Carter (2002), Furuta dan Salway (2006), dan Mullany, Becker, dan
Hindin (2007) yang mengungkapkan bahwa suami yang mendampingi istri ke pusat layanan kesehatan, mencari pertolongan medis, menyediakan transportasi, menyediakan biaya dan informasi tentang kehamilan. Penelitian Story et al. (2012) juga menemukan hal serupa bahwa dukungan emosional dan instrumental selama kehamilan memberikan pengaruh positif terhadap kehamilan dan persalinan. Sapkota et al. (2012) juga mengemukakan bahwa dukungan peran suami dalam mendampingi istri menjalani persalinan menjadi penyebab istri merasa memegang kendali (feels more in control) selama persalinan. Dukungan peran suami pada lingkup domestik dikemukakan Utamidewi (2017) yang mengungkapkan bahwa kebahagiaan lebih terasa dalam rumah tangga ketika suami membantu istri melakukan pekerjaan rumah tangga. Selain itu, dukungan sosial suami terhadap ibu menyusui dalam bentuk motivasi, perhatian, penghargaan, membantu mengasuh anak dan dukungan informasi tentang manfaat ASI memberikan dampak kebahagiaan, kenyamanan dan bahkan beban hidup yang dihadapi terasa berkurang (Annisa \& Swastiningsih, 2015).

Pada hasil penelitian lain menyebutkan, ibu hamil membutuhkan dukungan dari suami sebagai orang paling dekat dengannya karena dukungan suami memberikan dampak positif terhadap tingkat kecemasan yang dialami ibu hamil terutama pada periode kehamilan trimester ketiga (Diani \& Susilawati, 2013). Kecemasan pada ibu hamil merupakan kondisi psikologis yang dapat menghambat proses persalinan, misalnya jalan lahir kaku dan sulit terbuka, his tidak teratur, atau posisi bayi yang tidak turun. Kecemasan juga dapat menstimulasi pengeluaran hormon katekolamin yang dapat menghambat kerja atau aktivitas uterus (Marhamah, 2013). Bahkan kecemasan ibu hamil yang tidak diatasi dengan baik dapat mengakibatkan depresi kehamilan (antenatal depression) yang secara signifikan berkaitan dengan kelahiran prematur (preterm birth) dan berat badan lahir rendah (low birth weight) seperti yang diungkapkan Grote et al. (2010). Bahkan sebuah laporan tentang penyebab kematian ibu di Inggris menyebutkan masalah kesehatan mental sebagai penyebab tidak langsung morbiditas dan mortalitas ibu (Jarrett, 2017). Oleh karenanya, sejalan dengan penelitian ini, meningkatkan kualitas kehamilan dan juga memperlancar proses kelahiran bukan saja terkait dengan upaya-upaya peningkatan kualitas ibu secara fisik. Hasil penelitian ini menegaskan bahwa dukungan suami baik 
dalam peran domestic, ekonomi, maupun sosial terhadap istri pada saat hamil dan melahirkan terbukti secara nyata meningkatkan kepuasan istri ketika hamil dan melahirkan. Kepuasan istri terhadap kondisinya ini tentu saja akan menjadi kondisi psikologis yang penting untuk dapat hamil secara berkualitas dan melahirkan dengan resiko kematian ibu dan bayi yang semakin kecil.

\section{SIMPULAN DAN SARAN}

Pada penelitian ini, rata-rata usia istri dan suami berada pada kelompok usia dewasa awal. Rata-rata lama waktu menempuh pendidikan formal suami 9,36 tahun dan istri 9,87 tahun setara dengan lulus Sekolah Menengah Pertama. Pendapatan keluarga rata-rata sebesar Rp3.056.363,64 per bulan. Peran suami termasuk dalam kategori rendah dan kesejahteraan subjektif istri ketika hamil dan melahirkan berada pada kategori sedang. Tipologi keluarga berdasarkan peran suami dan kesejahteraan subjektif istri, sebagian besar berada pada Tipe 2 yaitu peran suami dan kesejahteraan subjektif istri keduanya tinggi. Pendidikan suami, pendapatan keluarga, dan peran suami khususnya domestic dan sosial berpengaruh positif signifikan terhadap kesejahteraan subjektif istri ketika hamil dan melahirkan.

Meskipun begitu, penelitian ini juga menemukan rata-rata peran suami masih belum tinggi. Sementara itu, peran suami berpengaruh positif secara nyata terhadap kesejahteraan subjektif istri ketika hamil dan melahirkan. Oleh karena itu, suami diharapkan meningkatkan kepekaan dan kepedulian terhadap kondisi istri yang sedang hamil dan atau melahirkan, meningkatkan pengetahuan tentang kehamilan dan masa nifas agar dapat memberikan dukungan kepada istri termasuk dalam kondisi tertentu harus siap dan mau menjalankan beberapa peran istri. Peningkatan peran suami diharapkan mampu meningkatkan kesejahteraan subjektif keluarga secara umum dan kesejahteraan subjektif istri yang sedang hamil dan atau melahirkan secara khusus.

\section{UCAPAN TERIMA KASIH}

Penulis mengucapkan terima kasih dan penghargaan yang tinggi kepada Kementerian Riset dan Pendidikan Tinggi (Kemenristekdikti) dan Lembaga Pengelola Dana Pendidikan (LPDP) Kementerian
Keuangan yang telah mendukng biaya pendidikan dan biaya riset penulis melaluli program Beasiswa Unggulan Dosen Indonesia - Dalam Negeri (BUDI-DN) Tahun 2016.

\section{DAFTAR PUSTAKA}

Aceleanu, M. I. (2012). Links between education, employment and quality of life: the case of romania. Management \& Marketing Challenges for the Knowledge Society. 7(4): 717-730.

Alio, A. P., Salihu, H. M., Kornosky, J. L., Richman, A. M., \& Marty, P. J. (2010). Feto-infant health and survival: does paternal involvement matter? Maternal and Child Health Journal, 14(6), 931937. https://doi.org/10.1007/s10995-0090531-9.

Annisa, L., \& Swastiningsih, N. (2015). Dukungan sosial dan dampak yang dirasakan oleh ibu menyusui dari suami, EMPATHY, Jurnal Fakultas Psikologi, 3(1); 16-22.

ASEAN Secretariat. (2017). ASEAN Statistical Report on Millennium Development Goals 2017. Jakarta (ID) ASEAN Secretariat.

Carter, M. (2002). Husbands and maternal health matters in rural Guatemala: wives' reports on their spouses' involvement in pregnancy and birth. Social Science and Medicine, 55(3), 437-450.

Chen, J., Murayama, S., \& Kamibeppu, K. (2010). Factors related to well-being among the elderly in urban China focusing on multiple roles. BioScience Trends, 4(2), 61-71.

Diani, L. P. P., \& Susilawati, L. K. P. A. (2013). Pengaruh dukungan suami terhadap istri yang mengalami kecemasan pada kehamilan trimester ketiga di Kabupaten Gianyar. Jurnal Psikologi Udayana, 1(1), 1-11.

Diener, E., Eunkook, M., Richard, E., \& Heidi, L. (1999). Subjective well-being: three decades of progress. Psychological Bulletin, 125(2), 276-302.

Diener, E., \& Seligman, M. E. P. (2004). Beyond money: toward an economy of well being. Psychological Science in the Public Interest. 5(1): 1-31.

Durayappah, A. (2010). The 3P Model: A General Theory of Subjective Well- 
Being. Springer Science+Business Media B.V.

Furuta, M., \& Salway, S. (2006). Women's position within the household as a determinant of maternal health care use in Nepal. International Family Planning Perspectives, 32(01), 017-027. https://doi.org/10.1363/3201706.

Gray, G. R., Ventis, D. G., \& Hayslip, B. Jr. (1992). Socio-Cognitive Skills as a determinant of life satisfaction in aged persons. The International Journal of Aging and Human Development. 35(3): 205-218.

Grote, N. K., Bridge, J. A., Gavin, A. R., Melville, J. L.. lyengar, S., \& Katon, W. J. (2010). A Meta-analysis of Depression During Pregnancy and the Risk of Preterm Birth, Low Birth Weight, and Intrauterine Growth Restriction. Archives General Psychiatry, 67(10); 1012-1024.

Hartoyo, \& Aniri, N. M. (2010) Analisis tingkat kesejahteraan keluarga pembudidaya ikan dan nonpembudidaya ikan di kabupaten Bogor, Jurnal IImu Keluarga \& Konsumen, 3(1) 64-73.

Inggriani, J., \& Nafik, M. H. R. (2015). Bagaimana peran istri dalam mencapai Maqashid Syariah: istri sebagai manajer keuangan. JESTT. 2(12); 1036-1051.

Jarrett, P. M., (2017). Pregnant women's experience of depression care. The Journal of Mental Health Training, Education and Practice. 11(1); 33-47.

Joo, S., \& Grable, J. E., (2004). An exploratory framework of the determinants of financial satisfaction. Journal of Family and Economic Issues. 25(1); 162-171.

Kartika, Q., \& Kanada, R., (2017). Peran ganda perempuan pada keluarga masyarakat petani: kasus istri petani di Kecamatan Merapi Selatan Kabupaten Lahat, An Nisa'a: Jurnal Kajian Gender dan Anak, 12(02); 151-162.

Kim, J. E., \& Moen, P. (2002). Retirement transitions, gender, and psychological well-being: a life-course, ecological model. Journal of Gerontology: Psychological Sciences 57(3); 212-222

Kusumo, R. A. B., Sunarti, E., \& Pranadji, D. K., (2008). Analisis peran gender serta hubungannya dengan kesejahteraan keluarga petani padi dan hortikultura di daerah pinggiran perkotaan. Media Gizi dan Keluarga, 32(2), 52-64.
Lewis, S., Lee, A., \& Simkhada, P. (2015). The role of husbands in maternal health and safe childbirth in rural Nepal: a qualitative study. BMC Pregnancy \& Childbirth, 15(162) 1-10.

Liamputtong, P., \& Naksook, C. (2003). Perceptions and experiences of motherhood, health and the husband's role among Thai women in Australia. Midwifery, 19(1), 27-36.

Madanijah, S., Briawan, D., Rimbawan \& Zulaikha. (2013). Defisiensi multi zat gizi mikro kombinasi dengan defisiensi protein pada ibu pra hamil, hamil dan menyusui di Bogor. Semnas Pagi 2013, Biokimia Gizi, Gizi Klinis dan Dietetik. 153-162.

Mageni., Nekesa, J., Mwagni, A., Mbugua, S., \& Mukhtar, V., (2013). Male involvement in maternal health care as a determinant of utilization of skilled birth attendants in Kenya. DHS Working Papers. (93). Calverton, Maryland (USA). ICl International.

Marhamah, A. (2013). Kecemasan dan problem focused ibu hamil dalam menjelang persalinan anak pertama di Loa Kulu Kalimantan Timur. E-Journal Psikologi. 1(3): 292-302.

Megawangi, R., (2014). Membiarkan Berbeda, Sudut Pandang Baru tentang Relasi Gender Edisi Revisi. Depok (ID): Indonesia Heritage Foundation.

Muladsih, O. R., Muflikhati, I., \& Herawati, T. (2011). Pola komunikasi, pengambilan keputusan dan kesejahteraan keluarga jarak jauh: Kasus pada keluarga mahasiswa pascasarjana. Jurnal IImu Keluarga \& Konsumen, 4(2); 121-129.

Mullany, C. B., Becker, S., \& Hindin, M. (2007). The Impact of including husbands in antenatal health education services on maternal health practices in Urban Nepal: results from a randomized controlled trial. Health education research, (22); 166-176

Plagnol, A. C. (2011). Financial satisfaction over the life course: The influence of assets and liabilities. Journal of Economic Psychology. 32(1); 45-64.

Puspitawati, H. (2009). Pengaruh strategi penyeimbangan antara aktivitas pekerjaan dan keluarga terhadap kesejahteraan keluarga subjektif pada perempuan bekerja di Bogor: analisis Structural Equation Modelling. Jurnal 
IImu Keluarga \& Konsumen, 2(2); 111121.

Puspitawati, H. (2012). Gender dan Keluarga Konsep dan Realita di Indonesia. Bogor: IPB Press.

Puspitawati, H., Simanjuntak, M., \& Hayati, L. (2012). Kontribusi ekonomi dan peran ganda perempuan serta pengaruhnya terhadap kesejahteraan subjektif. Jurnal IImu Keluarga \& Konsumen, 5(1); 11-18

Putri, D. P. K., \& Lestari, S. (2015). Pembagian peran dalam rumah tangga pada pasangan suami istri Jawa. Jurnal Penelitian Humaniora, 16(1); 72-85.

Raharjo, I. T., Puspitawati, H., Krisnatuti, D. (2015). Tekanan ekonomi, manajemen keuangan, dan kesejahteraan pada keluarga muda. Jurnal IImu Keluarga.\& Konsumen. 8(1): 38-48.

Rustikayanti, R. N., Kartika, I., \& Herawati, Y,. (2016). Adaptation of psychological changes in the third semester of pregnant women. The Southeast Asian Journal of Midwifery, 2(1): 45-49.

Sapkota, S., Kobayashi, T., Kakehashi, M., Baral, G., \& Yoshida, I. (2012). In the Nepalese context, can a husband's attendance during childbirth help his wife feel more in control of labour? BMC Pregnancy \& Childbirth, 12(49); 1-10

Story, W. T., Burgard, S. A., Lori, J. R., Taleb, F., Ali, N. A., \& Hoque, D. E. (2012). Husbands involvement in delivery care utilization in rural Bangladesh: A qualitative study. BMC Pregnancy and Childbirth, 12(28); 1-12

Sunarti, E., (2015). Ketahanan Keluarga Indonesia: Dari Kebijakan dan Penelitian Menuju Tindakan: Orasi IImiah Guru Besar IPB. Bogor (ID). IPB.

Tripathi, R. K. (2012). Quality of life: an important issue in geriatric research. Journal Gerontol Geriatrics Research. 1 (5); 1-12

Umami, R., \& Puspitasari, N. (2007). Peran Suami selama Proses Kehamilan sampai Nifas Istri. The Indonesian Journal of Public Health, 3(3); 101-107.

University of Toronto-Canada. (2008). Quality of Life Research Unit. Notes on Quality of Life.. http//www.gdrc.org. [diunduh 2018 Februari 10]

Utamidewi, W. (2017), Konstruksi makna istri tentang peran suami: Studi fenomenologi tentang istri sebagai wanita karir dan memiliki pendapatan yang lebih besar dari suami di Kota Jakarta. Jurnal Politikom Indonesiana, 2(2); 63-70.

Widoyo, R. (2015). Peningkatan peran suami dalam kesehatan ibu dan anak Indonesia. Jurnal Kesehatan Masyarakat Andalas, 9(2), 63-64.

Zhang, W., \& Liu, G. (2007). Childlessness, psychological well-being, and life satisfaction among the elderly in China. Journal of Cross-Cultural Gerontology (22); 185-203. 